UNIVERSITY OF CHITRAL JOURNAL OF LINGUISTICS AND LITERATURE

VOL. 2 | ISSUE II | JULY - DEC | 2018

ISSN (E): 2663-1512, ISSN (P): 2617-3611

\title{
On the Symbolism of Rain in A Farewell to Arms
}

\section{Mohammad Rahman}

Lecturer in English, Shaheed Benazir Bhutto University Sheringal, Dir Upper, Pakistan, rahmanmsw@gmail.com

\begin{abstract}
This paper critically analyzes the symbolic use of rain in A Farewell to Arms (1929). The researcher has applied Sapir-Whorf Hypothesis as a research tool for the analysis of the text. This hypothesis argues that the languages spoken by a person determines how one observes this world and that the peculiarities encoded in each language are all different from one another. It affirms that speakers of different languages reflect the world in pretty different ways. Hemingway's symbolic use of rain in A Farewell to Arms (1929) is denotative, connotative and ironical. The narrator and protagonist, Frederick Henry symbolically embodies his own perceptions about the world around him. He time and again talks about rain when something embarrassing is about to ensue like disease, injury, arrest, retreat, defeat, escape and even death. Secondly, Hemingway has connotatively used rain as a cleansing agent for washing the past memories out of his mind. Finally, the author has ironically used rain as a symbol when Henry insists on his love with Catherine Barkley while the latter being afraid of the rain finds herself dead in it.
\end{abstract}

Key Words: Arms, Farewell, Hypothesis, Rain, Symbolism

\section{Introduction}

A Farewell to Arms (1929) is a novel which is replete with a variety of symbols. Ernest Miller Hemingway (1899-1961) has made use of a variety of literary symbols which implicitly bear meanings for the readers. In addition to 'Rain' the other literary symbols recurrently used by Hemingway include mountains, seas, snow, hair, beard, military star, the seasons, plains, home, etc. But 'Rain' is the most recurring of all the symbols found in A Farewell to Arms (1929). It has been used more than a hundred times in the novel. There are two symbolic aspects of rain: Rain as bad luck and rain as fertilizing force. Rain often signifies the fertility and life force from above the sky. But Hemingway in many of his works associates it with a bad luck or suffering like death, defeat or failure. It stands as a synecdoche for all the unhappy moments of his life. It has never been supposed as a prophesy of a good omen for any of the characters in the novel.

A Farewell to Arms portrays the author's disillusionment with love and war. It is a tale of an American lieutenant Frederick Henry. He falls in love with an English nurse Catherine Barkley. He gives his services as an ambulance driver in the northern Italy in the wake of the First World War. Catherine Barkley on the other hand turns down Henry's love. She voluntarily serves the war 
UNIVERSITY OF CHITRAL JOURNAL OF LINGUISTICS AND LITERATURE

VOL. 2 | ISSUE II | JULY - DEC | 2018

ISSN (E): 2663-1512, ISSN (P): 2617-3611

victims. Although, she gets pregnant yet refuses to marry Frederick Henry. She ultimately dies in childbirth after Henry makes his way to Switzerland. Illinois is an American state where Hemingway was brought up and educated. This area receives sufficient rainfall during the winter as well as the summer season.

The term 'Symbolism, basically means the use of symbols to epitomize concepts in literature. It is the practice of assigning special meaning to phenomena, relationships, events, actions, things, persons, objects, situations, etc. A single symbol may carry several layers and systems of meanings. Authors deliberately or otherwise make use of various symbols to implicitly covey his message to the readers on subtle or contentious matters. Authors almost in all cultures and literatures use symbols for the efficacy as well as embellishment of their texts. There are two major categories of symbols. Conventional symbols, which means the same to all the readers. But there are symbols which vary with place, time and even culture.

The word 'Culture' whether used generally or specifically, delineates a particular way of life, whether of a people, a period, a group or humanity in general. In Cultural Studies as well as in History, it refers to 'Signifying or Symbolic Systems' while in Archaeology and Cultural Anthropology, it is concerned with the material production. Culture is said to be a certain mode of generating meanings and notions. It means what a particular thing, event or activity means to a particular nation or community. The concept of culture is very much akin to the concept that is recognized in Cultural Anthropology. It means that all humans live in a world which is replete with different meanings assigned by them to a variety of different phenomena.

\section{Theoretical Framework}

The researcher has applied Sapir-Whorf Hypothesis for the critical analysis of the author's symbolic use of 'Rain' in A Farewell to Arms (1929). "This hypothesis argues, first, that the language one speaks determines how one perceives the world, and, second, that the distinctions encoded in each language are all different from one another" (Salzmann, Stanlaw, \& Adachi, 2012). It claims that each culture and society lives in its own way and that each language embodies a world view. All the speakers of two different languages think about the world in quite different ways. Hence it is obviuos that language is a cultural phenomenon. Likewise, speakers within a culture see the world around them and thus make a way of life. Hence the meaning of words wheather it is denotative or connotative depends on context as well as culture.

\section{Analysis and Discussion}

The novel opens up with World War I as its backdrop. We see the protagonist, Frederick Hendry describing the marching troops. With the coming of the rain Henry says, “... and in the fall when the rains came the leaves all fell from the chestnut trees and the branches were bare and the trunks black with rain" (p. 10). The author has presented a gloomy image of the vicinity. The trees are bare, the trunks of the trees are black, the roads are muddy and the soldiers along with their rifles 
UNIVERSITY OF CHITRAL JOURNAL OF LINGUISTICS AND LITERATURE

VOL. 2 | ISSUE II | JULY - DEC | 2018

ISSN (E): 2663-1512, ISSN (P): 2617-3611

are wet. He associates the impending dangers with the autumnal rain which not only takes away all the beauties but also leaves many of the soldiers dead. "At the start of the winter came the permanent rain and with the rain came the cholera. But it was checked and in the end only seven thousand died of it in the army" (p. 11). It is rain which brings the deadly disease cholera along with it and consequently puts thousands of soldiers to death. One day, when Henry comes home from the Ospedale Maggiore, he is overcome by a heavy rain. He feels sickening during the night time and finds himself nauseated in the upcoming morning. The whites in his eyes has become yellow and that his family doctor says that he is suffering from the jaundice. He remains sick for two weeks, which badly affects his trip with Catherine to Pallanza.

While Henry is lying wounded at the hospital. Catherine is having a lot of qualms and queries about the forthcoming rain. "All right. I ' $\mathrm{m}$ afraid of the rain because sometimes I see me dead in it" "No" "And sometimes I see you dead in it" "It's all nonsense. It's only nonsense. I 'm not afraid of the rain. Oh, oh, God I wish I wasn't." She was crying. I comforted her and she stopped crying. But outside it kept on raining" (p. 143). Catherine has always been afraid of the rain. In her reply to Henry, she actually anticipates that she sees Frederick and herself dead in rain. Chapter twenty seven is characterized by intermittent showers of rain. The Italian begins to face a massive retreat at the hands of the Germans. "They fought in the dark in the rain and a counter-attack of scared men from the second line drove them back" (p. 207).

In an encounter with Catherine Barkley, Henry tries to ensure of his love with her. He affirms that he would love her what so ever the case may be. But on the other hand, Catherine being afraid of the rain seems ironical of the tragic consequences of her amorous advances with Fredrick Henry. In a reply to her question Henry insists on her love with her and says to her, "I II love you always." I will love you in the rain and in the snow and in the hail and--- what else is there?" on the other hand Catherine says to him, "All right. I'm afraid of the rain because sometimes I see me dead in it, "And sometimes I see you dead in it." It is the moment when Henry tries to console Catherine not be afraid of the rain while it keeps on raining outside of the room. Catherine is about to cry but Henry comforts her right on the spot.

Once the fog turns to rain. Henry and Catherine decide to hang out of the station. All of a sudden it begins to rain. With that Henry foretells something bad to happen, "there would be many sicks now the rains had started." (p. 203). Henry himself feels the rain falling on his face. The bombardment starts to the south and they has to face a sullen retreat which was following that rain. The Germans and Austrians has come down towards Cividale and Udine. Thus they has to evacuate all the hospitals. As soon as they reach Gorizia in the mid of the next day, the rain stops but all the city already remains unoccupied. The narrator's walking and standing recurrently in the rain presage the killing of many army officers and a substantial retreat. Being in a precarious situation Henry does not want to disclose his identity. He calmly remains German in the Italian uniform. He does not have any other option but to make an escape from that spot. 
UNIVERSITY OF CHITRAL JOURNAL OF LINGUISTICS AND LITERATURE

VOL. 2 | ISSUE II | JULY - DEC | 2018

ISSN (E): 2663-1512, ISSN (P): 2617-3611

In book four of the novel, the protagonist reaches Milan and joins with Catherine in a hotel. In the room of the hotel they can see the rain falling outside the windows. Henry wakes to listen to the rain smashing the panes of the window. In the dead of the night, the barman comes to them and informs them that they are going to be arrested in the morning. Their lives are in danger and they realize the gravity of the situation. In order to escape the German foes, they decide to go to Switzerland through a boat. It is still raining when they land on Switzerland. But this time it is a cheerful rain in Switzerland. There they are at least safe from the Germans.

The two lovers live happily for two months in Switzerland. In March it starts raining high up the mountains. They wait for the turning out of the weather but it rains for three days. On the third day of the rain they decide to go to Montreux. From there they are supposed to take the train to Lausanne where they wish to stop. It is again raining cats and dogs as they walked through the streets and later into the welcoming entrance of the grand hotel. From the room of the hotel Henry can look at the rain outside falling into the fountain of the garden.

After three weeks, the weather becomes quite warm and the spring is on its full bloom. They has a lot of fun in playing various games. "When there was a good day we had a splendid time and we never had a bad time.” (p.340). It is the time when Catherine is expecting the baby and they feel to somehow manage for it as the rainy days has almost gone and the weather is in their favor then.

The death of the new born baby is one of the most tragic events of the novel. It is like other sad events preceded by the rain. Having sit down on the chair at the hospital Frederick Henry said, "I could see nothing but the dark and the rain falling across the light from the window. So that was it. The baby was dead." (p. 357). After the death of the baby, Henry goes to enquire about Catherine's health. His walking through the rain up to the hospital is premonitory of a more tragic incident of the novel. The nurse takes Henry where Catherine lies on her death bed. Having found Catherine dead, Henry says, "It was like saying good-bye to a statue. After a while I went out and left the hospital and walked back to the hotel in the rain." (p. 363).

\section{Conclusion}

Sapir-Whorf Hypothesis attempts to determine the relationships between language, thought and culture. In cultures where rain is scarce, it symbolically means life and rebirth. As a man of letters, Hemingway symbolically make use of rain in 'A Farewell to Arms' (1929) is denotative, connotative and ironical. Through the mouth of his protagonist, Hemingway has embodied his own world. Henry time and again talks about rain when something embarrassing is about to ensue like disease, injury, arrest, retreat, defeat, escape and death. In the last lines of the novel, Hemingway has connotatively used rain as a cleansing agent for washing the past memories out of his mind. He walks through the rain not because that something evil is about to come up but rather he is having a kind of catharsis. He wants to forget about what has happened to Catherine and his baby 


\section{UNIVERSITY OF CHITRAL JOURNAL OF LINGUISTICS AND LITERATURE}

after a cesarean operation. Symbolically, the rain here has a soothing effect on Frederick Henry. Last but not least, the author has ironically used rain as a literary symbol. When Henry insists on his love with Catherine he says to her, "I 11 love you in the rain and in the snow and in the hail--what else is here?" Catherine seems quite fearful when she says that she is afraid of rain, and that she finds herself dead in it. Meanwhile Henry tries to console her while it is still raining outside the rain.

\section{References}

Barbera, M. P. (Ed.). (2010). A Dictionary of Cultural and Critical Theory (Second ed.). Chichester, West Sussex, UK: Wiley-Blackwell, AJohn Wiley and Sons, Ltd Publication.

Barry, P. (2002). Beginning Theory, An Introduction to Literary and Cultural Theory (2nd ed.). Manchester University Press.

Bloom, H. (2007). Modern Critical Interpretations: Ernest Hemingway's A Farewell to Arms. New Delhi: Vinod Vasishtha Viva Books Private Limited.

Bloom, H. (2010). Bloom's Guides: A Farewell to Arms. New York, USA: Infobase Publishing.

Edgar, A., \& Sedgwick, P. (2002). Cultural Theory: The Key Thinkers. London: Routledge.

Edgar, A., \& Sedgwick, P. (2008). Cultural Theory: The Key Concepts (2nd ed.). Oxfordshire: Routledge.

Hemingway, E. (2012). A Farewell to Arms. New Delhi: Prakash Books.

Salzmann, Z., Stanlaw, J., \& Adachi, N. (2012). Language, Culture, and Society (5th ed.). Philadelphia: Wsetview Press.

\begin{tabular}{|l|l|}
\hline CC 2017 by the author. Licensee University of Chitral, Journal of Linguistics \& \\
Literature, Pakistan. This article is an open access article distributed under the \\
terms and conditions of the Creative Commons Attribution (CC BY) \\
(http://creativecommons.org/licenses/by/4.0/).
\end{tabular}

